\title{
The Autobiography of Thomas Whythorne: An Early Elizabethan Context for Poetry
}

\author{
DAVID R. SHORE
}

I

In the annals of English literature the recently discovered Autobiography of Thomas Whythorne (1528-96) is something of an anomaly. Why thorne travelled in Italy, the ostensible birthplace of the genre, but he was there in the early 1550s, before Cellini and Cardano wrote their autobiographies. When he composed his own, probably in 1576, he was apparently "uninfluenced by any earlier autobiography," 1 and he wrote without benefit of most of the imaginative and spiritual resources that in the seventeenth century would nourish the impulse to chronicle the affairs of self. ${ }^{2}$ Somehow he managed to produce "the first sustained 'modern' autobiography written by an Englishman," 3 though it would be almost a quarter of a century before another English secular autobiography would be written and well over a century before the non-sectarian autobiography would become an established feature of English letters. ${ }^{4}$ Yet Why thorne is a most unlikely innovator. His work reveals him to us as a man instinctively cautious and conservative, always fearful of jeopardizing his hard-won place in the lower rungs of middle-class society - hardly the type to make a bold generic leap even in an unpublished manuscript (the work did not see print until 1961). Indeed, the more closely we examine the Autobiography, the more apparent it becomes that Whythorne and his manuscript are both very much products of their age. The work we recognize as the first modern autobiography is, I want to argue, a product, not of seventeenth-century attitudes toward the self, but mid-sixteenth-century attitudes toward poetry. Although Why thorne was a practising musician for whom the writing of poetry was a secondary activity, his manuscript contains over two hundred poems that are, in fact, the reason for the manuscript's existence. Moreover, quite apart from the interesting light it casts on its author's life, the manuscript casts an even more interesting light on the broader question of the status of poetry in those obscure decades preceding Spenser's Shepheardes Calender and Sidney's Apology for Poetry.

To view Whythorne as a mid-sixteenth-century poet is to locate him 
in a period often thought of as a poetic waste land. It is salutary to reflect that, although the early Elizabethan decades did not produce many eternal lines, they were nevertheless a time when the general level of enthusiasm for both reading and writing poetry ran high. The strongest evidence comes from those who saw this passion for poetry as something reprehensible, at least in its manifestations. Roger Ascham, for example, in a passage in the Scholemaster probably written about five years before the work's posthumous publication in 1570, launches a vehement attack on the "rude beggerly ryming" that characterizes contemporary verse, and argues the merits of naturalizing the quantitative measures of classical verse:

surelie than rash ignorant heads, which now can easely recken up fourten sillabes, and easelie stumble on every Ryme, either durst not, for lacke of such learnyng: or els would not, in avoyding such labor, be so busie, as everie where they be: and shoppes in London should not be so full of lewd and rude rymes, as commonlie they are. But now, the ripest of tonge, be readiest to write: And many dayly in setting out bookes and ballettes make great shew of blossomes and buddes, in whom is neither, roote of learning, nor frute of wisdom at all. ${ }^{5}$

What surprises is not the humanist's hostility to the displacement of classical verse forms; rather it is the image Ascham's words convey of early Elizabethan London as a place of fervent literary activity - not just among the courtiers for whom, as in the reign of Henry VIII, poetry was once again becoming a desirable polite accomplishment, ${ }^{6}$ nor just among the students of the Inns of Court, who often seem to have devoted as much attention to poetry as to law, but among the literate populace as a whole. Everywhere, it seemed to Ascham - and his testimony is not unsupported - people were meddling with poetry. ${ }^{7}$

Among them, of course, was Thomas Whythorne, whose very minor poetic talent has for posterity been rendered invaluable by his extensive comments on the exercise of that talent. His autobiography, as its editor observes, is "the only one in literary history in which a poet explains in detail the setting, circumstances, feelings, and meanings behind each of his poems." 8 One of the great advantages of Whythorne's work is that it allows us some insight into the precise nature of a poetic enthusiasm that to men like Ascham appeared merely a mockery of good letters.

Yet it should be confessed that the reader who comes to the Autobiography eager to explore a fresh if minor field of Elizabethan poetry is apt to experience an initial sense of disappointment. For Whythorne's poetic enthusiasm, though certainly genuine, is prone to manifest itself in ways surprising to those whose ideas about sixteenth-century poetry have been formed by reading poets like Sidney, Spenser, Marlowe, Shakespeare, Daniel and Drayton. If there is one thing beyond their 
sheer love for poetry that unites those late Elizabethans, it is their variously manifested belief in the idea of the poem, ${ }^{9}$ the unique ability of the poet to create a world that in some way transcends the normal bounds of space and time. Nature's world, says Sidney, "is brasen, the Poets only deliver a golden." 10 Whythorne may well have read Sidney's words (though not, unfortunately, until after the Autobiography had been written), but I suspect he would have read them with little comprehension. Whythorne had a passion for poetry, but it was a passion very much rooted in the here and now of day-to-day existence.

The circumstances in which Whythorne turns to poetry vary greatly, but a few examples will suggest some initial generalizations. Consider first one of the early poems in the volume, written after Whythorne had served for more than three years as "servant and scholar" to the poet and dramatist John Heywood. At the end of this time, around 1548, he set out on his own and pondered, rather worriedly, the problems involved in gaining a livelihood from his music. "I saw," he tells us, "how I must seek to live of myself, for the which it behoved me to cast my wits so many ways, and they being never troubled so much that way before, as I was almost at my wits' end." 11 In the midst of his troubles, he turned to writing poetry:
My tender years ere I out went,
I wished each day they had been spent,
Thinking that by my liberty
Much ease and joy should come to me.
But now I see, more than before,
That youth hath brought of cares great store,
Which to take well and them digest
I think is best to purchase rest. (p. 10; p. 19)

The interesting feature of this admittedly rather unremarkable excursion into verse is the value it had for Whythorne himself. He wrote the poem, he says, "to clear my mind in this perplexity," and it is apparent, I think, that in this poem at least reducing his thoughts to metre and rhyme is essentially an exercise in self-discipline, a means of imposing order on a state of mental and emotional turmoil.

Something very similar happens during a frustrating convalescence from a lengthy illness when he copes with a growing sense of discontentment by again turning to poetry: "In these days I would wreak mine anger altogether with pen and ink upon paper, because that the timorousness that then was in me, which was bred by the melancholy left as a relic of my ague, and the weakness of my young courage, would not stir nor provoke me to do otherwise" (p. 27; p. 36). The result is a poem making the traditional affirmation, "all my hope is in my God,/Whose look Dame Fortune dare not bide." The formal discipline of poetry 
becomes here an instrument of spiritual discipline, a means of successfully confronting the tribulations imposed on him by the disease. Whythorne, wryly acknowledging the childishness of his impatience, compares his writing of the poem to the action of "a young, shrewish maiden... who, when she was much angered, would straightways go into a cellar that her father had, and there would she with her teeth bite upon a post a long time, till she had digested the rage of her choleric humour."

Other examples of using poetry to approach a state of humility could be culled from the pages of the Autobiography, but I do not want to give the entirely misleading impression that Whythorne is a sixteenthcentury version of George Herbert. A more accurate and useful suggestion would be that poetry for Whythorne is not a mode of vision but a mode of thought - or, better, a way of ordering thought. There is no turning away in Whythorne's poetry from the practical concerns of the moment. To write a poem is to turn toward those concerns, to grapple with them so that the poet may experience them with a new sense of formal coherence. The discipline of verse may, as in the above examples, enable the poet to reach a conclusion, to enforce a resolution, or, as in the following example, to provide a convenient aid to memory:

The pleasant and the gentle speech, where countenance like doth show,

Courteous behaviour and gesture, where manners mild do grow,

Of all things in absence to make the best with good report,

Doth win and keep faithful friendship, where reason doth resort.

(p. 63; p. 77)

This is nothing but a verse rendering of some words Whythorne encountered in his reading: "Fair speech in presence, with good report in absence, and like manners in fellowship, obtaineth great friendship." He thought the saying a "pretty" one, "which to follow I thought should be very expedient for me to do, not only at all times else, but chiefly at this time." Whythorne was trying to bolster his courage for a courtship that never did come to fruition; he therefore put the saying "thus in metre" in order to "print the substance of this saying the deeper in my remembrance."

Sidney in the Apology boldly asserts that "it is not riming and versing that maketh a Poet." 12 For Whythorne, on the other hand, it would seem that it is precisely rhyming and versing that do make a poem - for in this particular example there are only the formal characteristics of verse to distinguish between the prose of Whythorne's reading and the poem of his writing. It would be a mistake, though, to extend this observation into a denial of poetry's significance to a man such as Whythorne (or to his many contemporaries for whom he has been left to stand as an articulate representative). While he was at Oxford, Whythorne received from his uncle and guardian a hortative letter in which he was advised, 
"Wherefore now ply your learning so as you may live thereby hereafter. There is a philosopher named Plato who giveth counsel to choose the best way in living, or to live by, the which use and custom shall make easy and pleasant. Also another philosopher named Pythagoras doth say that when a man is past the first difficulty of virtue, all after is easy and plain" (p. 5; p. 12).

The result was a three-stanza poem, the last two of which comprise the substance of his uncle's words:

The wise Plato as thus doth counsel give:

Choose thou the ways the best thou canst to live,

The which custom and use thereof shall make

Pleasant, if not too much thereof thou take.

Pythagoras (I read) doth also say

That when a man is entered on the way,

Past the first brunt and eke difficulty

Of virtues, then all after be easy. (p.9; p. 18)

Why thorne, I would suggest, thought that his uncle's words merited not only to be remembered but also to be accorded the formal dignity of verse.

We are today probably precluded from sharing in the delight the sixteenth-century reader found in highly stylized language. We spend too much of our time in contact with carefully ordered discourse, both written and oral, to recreate for ourselves the response of an age for whom such contacts - despite a rising literacy rate and a new proliferation of printed books - still had the freshness of novelty, an age for whom formal language was something quite apart from the normal sphere of verbal activity. Poulter's measure and euphuism, to take the most obvious examples, are to us little more than puzzling aberrations of taste; to the sixteenth century, as their popularity attests, they must have been opportunities to retreat momentarily into a more ordered, a more coherent world. It is scarcely an exaggeration to say that for Whythorne poetry is at times a means of lightening "the heavy and the weary weight/ Of all this unintelligible world" (though the relief is not such as would have sufficed for Wordsworth). Such is the suggestion when Whythorne, disappointed in the progress of his courtship and in the object of his affections, versifies a commonplace on the value of patience: "to ease my mind," he says by way of a preface, "I made this sonnet following" (p. 65; p. 79).

But if poetry is an escape into coherence, the matter clarified always remains the prosaic experience of day-to-day existence. Poetry is never for Whythorne an escape into a golden world of the imagination, it encourages no metaphysical distinctions between prose and poetry, between life and art, between England and Faeryland. Whythorne's poetry, in other words, is in the strictest sense of the word occasional; 
it is verse written very much and deliberately not for all time but for an age. Indeed, it seems to me one of the most important legacies of Why thorne's Autobiography that it reveals to us the importance at least one early Elizabethan author placed on the relationship between his poems and the times, places, and circumstances that gave them birth.

This relationship is most demonstrable and most obviously significant in the case of the verse epistle, many of which are recorded in Why thorne's manuscript. For example, the one he wrote to the young girl who began a flirtation by leaving some anonymous verses in his gittern strings (pp. 21-22; pp. 30-31) is as clearly tied to its occasion as any letter addressed from one individual to another and dealing with a particular subject. (In fact this rather clumsy epistle is nothing more than a transposition into verse of an equally clumsy reply Whythorne wrote in prose - he was the kind of lover whom one occasionally expects to encounter in the more satirical pages of Jane Austen.) It should be no less obvious, however, that the poems cited above are equally responses to particular occasions: his momentary dismay as he confronts an uncertain future, or his pleasure at receiving a letter whose sentiments well accord with his rather puritanical temperament. It would be an easy task to go through the Autobiography and point out instance after instance in which Whythorne explicitly asserts the occasional nature of his poetry, often indeed introducing a poem with such words as "I took occasion upon that to write thus" (p. 120; p. 139). In this particular case, it might be well to mention, "that" refers to his pondering of the vagaries of wealth among the urban merchant classes and his recollection of something he had read concerning the suspect nature of sudden-gotten gains; "thus" refers to the poetic result:

\footnotetext{
I cannot deem them happy sure,

Who can but only crack of muck,

I mean riches, which worldlings lure

From heavenly cares themselves to pluck.

But if virtue to wealth joined be,

Twice happy then they be, I see.
}

Of course, repeatedly demonstrating the relation between poem and occasion is clearly not enough to define adequately Why thorne's attitude toward poetry or, more important, the implications of that attitude for our understanding of the Autobiography and the age in which it was written.

The definition can be refined by continuing the comparison suggested by my earlier quotation from Wordsworth. Though there is an obvious element of absurdity in setting anything by Whythorne beside the genius of "Tintern Abbey," it is nevertheless with that quintessential Romantic poem that I should like briefly to compare something written 
by Whythorne at a time when he was angrily deciding to part from a couple who had engaged him to tutor their children and who had then, as he thought, treated him rather shabbily:

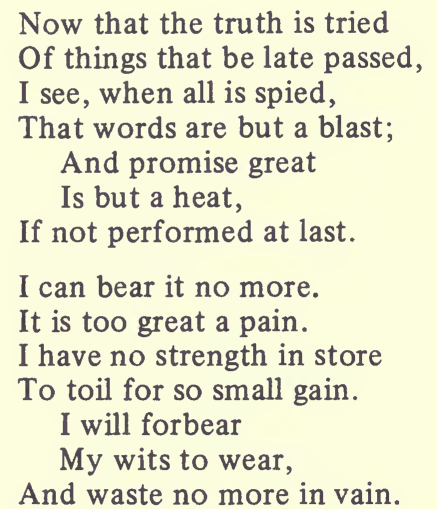

Too weak my brains now be

Such wrangling weight to wield.

A back not broad, ye see,

Big burdens carry seld.

Then why should I,

Thus foolishly,

As thrall be still so held?

But to provide in time

These troubles to delay,

And do no farther climb,

But go another way;

Proving if I

Can elsewhere spy

And find a better stay. (pp. 172-73; pp. 207-8)

Like Wordsworth's, Whythorne's poem records the poet's confrontation with a perplexing situation. By the end of "Tintern Abbey" Wordsworth attains a mental tranquillity that enables him to accept the evidence of delights forever lost. By the end of his poem, Whythorne has reduced to the order of verse both his anger and his newly formulated resolve. The process is clearly therapeutic: Whythorne refers to the writing of the poem as having "thus eased my mind for that matter" (p. 173; p. 209). Both poems are in a sense occasional. At the same time, though, it should be obvious that the difference between them is not simply that between genius and mediocrity. "Tintern Abbey" certainly evokes a particular time, place, and set of circumstances, but the poem is nevertheless entirely self-contained; the poem itself is adequate evocation and recreation of the occasion that gave it birth. Whythorne's poem, on the other hand, stems from a particular occasion but does not itself 
recreate the occasion. So long as it stands alone, Whythorne's poem remains something partial; it requires in order wholly to be understood the context and commentary that the Autobiography provides: "Here note that the word 'wield' aforesaid, although it may be understood to mean 'sustain, lift or bear' in one place of this foresaid song, so it may be taken as the name of the parish where my foresaid scholars did dwell. And whereas I do say that I will climb no farther, it is because that when I was to ride unto their house, I should ride up a high hill ere I came at it. And therefore I did say that I will no farther climb that hill" (p. 173, p. 208). Clearly this poem is not a thing unto itself; it fully exists, is fully meaningful, only within an awareness of circumstances extending beyond its own boundaries.

Although this particular poem requires a kind of elucidation seldom necessary with Whythorne's verse (his verbal ingenuity seldom extends to such subtleties as the play on "wield" and "Weald"), the concern to locate the poem within the circumstances that led to its composition is nonetheless typical of the Autobiography and a direct consequence of Whythorne's attitude to poetry in general. For Whythorne there is, I believe, no clear dividing line between the reality the poet creates and the reality prompting him to create. I am suggesting, in other words, not only that Whythorne's little poem on the ideas of Plato and Pythagoras was occasioned by a letter from his uncle, but that the relationship between the letter and the poem is for Whythorne part of the meaning of that poem; that the personal problems he confronted and the state of mind in which he wrote are part of the meaning of the poem he wrote on the cares of youth; that, even in the case of a poem such as the one quoted above on the relationship between wealth and virtue, a poem whose subject would appear to us to be "broad and generic and of what we might call persistent human significance" (to borrow one critic's definition of the kind of poetry being written in the early Elizabethan decades ${ }^{13}$ ), the full meaning of the poem, at least in the eyes of its author, is only available to those who are aware of the occasion that prompted the poet to write.

It is this attitude toward poetry that largely explains the otherwise perplexing existence of Whythorne's manuscript. He himself of course never referred to his work as an autobiography - the word did not come into use until the nineteenth century (OED), and the title of the modern editions derives from their editor, Professor Osborn. Whythorne's own title-page (printed by Osborn), while not ignoring the autobiographical revelations to come, establishes a significantly different emphasis by describing the volume as "A book of songs and sonnets, with long discourses set with them, of the child's life, together with a young man's life, and entering into the old man's life." The opening words recall 
in 1557, and the recollection is not inappropriate for a work whose primary justification is to be found, I believe, not so much in Whythorne's desire to narrate his personal history as in his desire adequately to present his poetic achievement.

Whythorne himself gives two initial reasons for preparing the manuscript he addressed to an unidentified friend. The first is that he is merely reciprocating his friend's own personal disclosures: "because that you did impart unto me at our last being together some of your private and secret affairs past, and also some of the secret purposes and intents the which have lain hid and been as it were entombed in your heart, I, to gratify your good opinion had of me, do now lay open unto you the most part of all my private affairs and secrets, accomplished from my childhood until the day of the date hereof" (p. 1; p. 3). Whatever revelations this friend may have made, they are unlikely to have been of the magnitude of a manuscript several hundred pages long. The event seems inadequate to explain so elaborate a response.

Moreover, although Osborn tends to accept Whythorne's account here at face value, ${ }^{14}$ it seems to me almost certainly factitious. Whythorne's introductory remarks were written about 1576 . Several pages into his manuscript he records the first and presumably the earliest poem in the volume, written a little over a quarter of a century before. The poem summarizes the first two decades of Whythorne's life (and so closely echoes the preceding pages that it appears Whythorne - in a reversal of his more frequent practice - used the verse as a basis for the prose). Here is his prefatory explanation of the poem's occasion: "whereas a friend of mine, nigh about the end of the time that I was with Mr. Heywood, did upon occasions moved declare unto me the state of his life for a certain time, I, to requite him, took occasion for an exercise to write unto him in metre the effect of that which is before rehearsed, in such sort as here followingly I have set it" (p. 7; p. 14). The hundred-line poem then begins with the words,

My faithful friend, since that thou didst impart

The secrets that lay hid within thy heart

To me, when we together last did talk,

To thee therefore, my heart and pen shall walk... .

Perhaps Whythorne was the kind of sympathetic listener who attracts personal confessions and repeatedly felt obliged to reply in kind. It seems to me more likely, though, that when in 1576 Whythorne set out to compile his manuscript he saw in the opening of that near-to-hand youthful poem a convenient means of justifying to his reader the rather unusual task he was undertaking.

Also, the care with which Whythorne throughout the volume protects 
the anonymity of most of the actors in his personal drama suggests that he was mentally addressing a wider audience than a single close friend. Quite possibly he contemplated publishing the work to demonstrate talents supplementing those shown by his madrigals of 1571. (George Gascoigne had after all published something rather similar to the Autobiography in the Hundreth Sundrie Flowers of 1573 and gained, if not renown, at least a certain degree of notoriety.) ${ }^{15}$ In any case, I would suggest that the friend to whom Whythorne addresses his work is an authorial convenience rather like that sixteenth-century tribe of authors' acquaintances who, according to a convenient fiction, repeatedly disregarded earnest injunctions to the contrary by betraying into the hands of printers manuscripts with which they had been naively entrusted. The betrayal of trust, the need to reply in kind to a friend - both are essentially means of partially displacing responsibility for a disclosure the author fears may be thought to be of doubtful propriety. ${ }^{16}$

The first part, then, of Whythorne's account of his motives in writing the Autobiography suggests little more than a desire to receive a favourable hearing - and his cause for concern was entirely genuine in an age when autobiography was unknown and poetry, especially contemporary poetry, was as disreputable as it was popular. ${ }^{17}$ The second part of his account, while less calculated to win over a hostile audience, is more illuminating as to Whythorne's actual intentions. After telling his friend that he writes the story of his life in order "to gratify you withal," he goes on to explain that he has an additional purpose, one directly related to the numerous poems the volume contains: "so am I partly enforced thereunto, because I do think it needful not only to show you the cause why I wrote them, but also to open my secret meaning in divers of them, as well in words and sentences, as in the whole of the same, lest you should think them to be made to smaller purpose than I did mean" (p. 1 ; p. 3). Here, I have no doubt, we have the real reason for the Autobiography's existence. Whythorne set out not to create a new English literary genre but simply to provide an adequately annotated collection of his very conventional poetry: "Recalling to mind my promise made unto you," he says in his opening sentence, "I have here sent you the copies of such songs and sonnets as I have made from time to time until the writing hereof."

That the primary concern of Whythorne's manuscript is with the poetic achievement rather than the autobiographical record seems to me apparent both from his opening remarks and from his pervasive concern throughout the work to establish the occasions on which his poems were written. I might mention, though, one further piece of evidence for this view of the Autobiography, and that is the manner in which Whythorne records his foreign travels. In the early 1550s Whythorne 
spent about six months in Flanders and Brabant. "What I learned and noted there," he tells us, "it were too long to show and set down in this place. Wherefore I will pass unto my purpose, which is to let you understand that two sonnets I made when I was in that country" (p. 49; p.61; italics mine). There follow two short poems on the dangers of drunkenness, together with some brief account of the circumstances attendant on their writing. His journey through Germany receives no more than a few sentences to explain the occasion of a third poem on the same subject, while his account of the half year he spent in Italy is restricted almost entirely to the recording of a few lines of Italian graffitti he discovered and to which he contributed some postscripts in Italian and English (and presumably felt confident that the original scribbler would confess himself intellectually bested when he read Whythorne's final devastating couplet: "In Public place nothing write thou,/ Except good skill therein thou show" [p. 51; p. 63]). The most detailed account of his travels to appear in the manuscript is, significantly, in verse - a 153line summary of the journey written after his return to England (pp.5457 ; pp. 66-71). Whythorne by no means found his journey lacking in a wider range of interest than these remarks might suggest; he did in fact write a (now lost) prose book "of my travel and of the things that I noted in the time of my travel; and also of the original and beginning of people of those countries" (p. 53; p. 65). It is just that such details do not properly belong in a work whose primary justification, in its author's eyes, is to provide a context necessary for fully understanding and appreciating a collection of poetry.

Of course merely to describe Whythorne's manuscript as an annotated poetic miscellany would distort his actual achievement. It is obvious that, as his work proceeded, Whythorne found his task expanding to meet the demands characteristic of a genre of which he undoubtedly had no preconception. Each individual life necessarily holds a powerful fascination for the individual himself, even in an age when that fascination is not acknowledged as a proper subject for literature. As Whythorne's personal history unfolds we see the story from time to time attracting more attention than the need to establish a context for the poetry will fully explain - the encounter with Mistress Elsabeth, for example (pp. 73-79; pp. 86-92), or the affair of the twenty-pound widow (pp. 150-71; pp. 185-207). Indeed, Why thorne's early autobiographical poem (pp. 79 ; pp. 14-17) suggests that he began life with a stronger propensity than most to regard his private and largely secular adventures as matters deserving serious consideration. I would by no means wish to dispute Osborn's description of Whythorne's work as the first English autobiography, and Whythorne himself suggests very near the beginning of his manuscript that he is attracted, not only by the goal of providing a 
commentary that will do justice to his poetry, but also by a very different goal:

\begin{abstract}
When I was a child, I did as a child, and when I was a young man, weening then that young men were as wise as the old experienced men be (as indeed some be, although not many), but now I wot, though I am not very old, that there remains many follies in young men. The which, I dare warrant you, ye may soon espy by my doings in my young life by reading of this following (p. 1, p. 4).
\end{abstract}

Beneath this highly conventional language lurks the author's aspiration to impose on the story of his life the coherence of form belonging to art. $^{18}$ But if Whythorne is in his way the prophet of a literary tradition yet scarcely conceived, I would nevertheless continue to argue that the fostering of the autobiographical impulse in England in 1576 is almost entirely to be explained by the fact that Whythorne was an early Elizabethan poet seeking to explicate his poetry in a manner fully in accord with the attitudes of his day. That this attempt allowed him to initiate a genre new to English literature is a fortunate accident of literary history, but an accident none the less.

Wythorne's provision of the autobiographical circumstances surrounding his poetry is roughly comparable to Tottel's prefixing the poems collected in his Miscellany with such titles as "The lover sheweth how he is forsaken of such as he sometime enjoyed," and "The lover rejoyseth against fortune that by hindering his sute had happily made him forsake his folly" (both by Wyatt). Titles like these were originally unnecessary for courtly makers presenting their work to an audience that itself provided the occasion for poetry; but when this same poetry was presented to a larger, more public audience, the printer obviously held it desirable to establish a sufficiently clear definition of occasion to enable the poetry to be read with some sense of meaningful participation. Whythorne of course writes from a greater knowledge of poetic origins than does Tottel, and, as we have seen, with a greater personal incentive to provide full circumstantial detail. But if Whythorne's contexts are more fully realized than those provided by Tottel - or indeed by almost any of his contemporaries (I leave room for the probable exception of Gascoigne) - the attempt to locate poetry in its occasional origins stems in both from a common impulse, a common view that poetry is something enmeshed in the fabric of day-to-day existence and not something set apart in a golden world of the imagination.

There have been a number of attempts to view the development of English poetry in the sixteenth century in terms of changing or conflicting attitudes toward the proper language of poetry. The most important of these attempts have been by C.S. Lewis, in his chapters on "drab" and "golden" verse in his volume on the sixteenth century in the Oxford 
History of English Literature, and by Yvor Winters, in his 1939 attack on the "perversion" of poetry by such "Petrarchists" as Sidney and Spenser and his defence of the main line of English poetry as exemplified by the plain style of their immediate predecessors. ${ }^{19}$ Such attempts to define the principles underlying poetry's progress in the sixteenth century in terms of contrasting stylistic ideals have never in my view proved entirely satisfactory. A full exploration of this subject, though, would require more space than can be allowed here. At present I wish only to suggest that attitudes towards the proper language of poetry are largely determined by attitudes concerning the nature of poetry itself, and that these attitudes underwent in England a fundamental change in the latter decades of the sixteenth century.

If we are to understand the milieu that produced Spenser's Calender, Sidney's Apology, and the remarkable profusion of poetry of the $1580 \mathrm{~s}$ and $90 \mathrm{~s}$, we must first understand the dominance and the implications of the poetic attitudes characterizing the preceding decades. Thomas Whythorne himself is not in my opinion much of a poet - it is difficult to say more in his favour than that he is prolific, conscientious, and occasionally charmingly naive. Even if Winters' crusade to exalt as the century's great achievement the poetry of Googe, Turberville and Gascoigne were to win more disciples than he seems yet to have acquired, ${ }^{20}$ it is unlikely that Whythorne would ever be accorded more than a very minor place in the mid-century procession of English poets. But I believe that the poetic focus of Whythorne's manuscript gives him an importance that he does not intrinscially possess either as poet or (except for his historical precedence) as an autobiographer.

To an extent largely unappreciated by modern criticism, sixteenthcentury. English poetry before Spenser and Sidney was conditioned by an assumption that poetry is something occasional and set apart from other forms of writing only by its verbal dexterity and its use of metre and rhyme. Poets did not simply and suddenly get better in the 1580 s and 90s; they learned or were taught to see themselves as engaged in an activity different and more exciting than that perceived by their predecessors. Good poetry was not precluded by the attitudes of the midcentury - after all, the attitudes that produced Thomas Whythorne also produced George Gascoigne, and if we are tempted to deride Whythorne's translations of prose into verse we need only remember Jonson's remark to Drummond of Hawthornden that his own verse he wrote "first in prose, for so his master Cambden had Learned him" 21 - but poetry in such a climate could not be seen as a unique form of intellectual activity, something distinguishing its practitioner as possessing more than a mere facility with language. Poetry's popularity in the mid century was of course no argument for its respectability. Whythorne, for all his 
obvious love for and even emotional near dependence on poetry, echoes the serious opinion of his day in saying that "poetical matters are but vain" (p. 148; p. 183). This refusal to acknowledge any peculiar value to the writing or reading of poetry was in the 1560 s and 70 s a serious obstacle to poetic progress. Out of the need to convince, not just the foes of poetry, but more particularly its friends that the poet is more than a manipulator of language, more than a man bringing a degree of formality to the thoughts and deeds of everyday and everyman, grew such vindications of the poet's art as Spenser's golden world of song in the April eclogue of the Shepheardes Calender and Sidney's description of the poet as "freely ranging onely within the Zodiack of his owne wit." ${ }^{22}$ Gradually, too, there grew to dominance that new attitude to poetry that today we think of as characteristically Elizabethan. The great value of Whythorne's Autobiography is that it provides us with first-hand evidence for what would otherwise remain a largely unprovable hypothesis derived from those poems that remain of the century's middle decades; it allows us direct contact with the soil that nourished, though only through contradiction, much of the greatest poetry England has ever produced.

University of Ottawa

\section{Notes}

1 James M. Osborn, The Beginnings of Autobiography in England (Los Angeles, 1960), p. 24.

2 For a consideration of the impulse to autobiography in Elizabethan literature see Rudolf Gottfried, "Autobiography and Art: An Elizabethan Borderland," Literary Criticism and Historical Understanding, Selected Papers from the English Institute, ed. Philip Damon (New York, 1967), pp. 109-34.

3 Osborn, Beginnings, p. 23.

4 The Autobiography of Simon Forman (1552-1611), ed. J.O. Halliwell (London, 1849), was written in 1600 . On the development of autobiography through the seventeenth century see Paul Delany, British Autobiography in the Seventeenth Century (London, 1969).

5 Roger Ascham, The Scholemaster, ed. Edward Arber (London, 1913), pp. 145, 146. I have normalized the use of $\mathrm{u}, \mathrm{v}$, and $\mathrm{j}$ in all quotations.

6 See Ralph M. Sargent, At the Court of Queen Elizabeth: The Life and Lyrics of Sir Edward Dyer (London, 1935).

7 Cf., for example, E.K.'s alliterative fury in the epistle prefatory to the Shepheardes Calender at "the rakehellye route of our ragged rymers," in Elizabethan Critical Essays, ed. G. Gregory Smith, 2 vols. (London, 1904), I, 131; Richard Stanyhurst's exclamation in the dedication to his translation of the Aeneid (1582): "Good, God, what a frye of such wooden rythmours dooth swarme in stacioners shops!" in Smith, I, 141; and Sidney's remark in the Apology that "now, as if all the Muses were gotte with childe, to bring foorth bastard Poets, without any commission they doe poste over the banckes of Helicon, tyll they make the readers more weary then Post-horses," in Smith, I, 194.

8 James M. Osborn, ed., The Autobiography of Thomas Whythorne (Oxford, 1961), p. lv. Gottfried, "Autobiography and Art," p. 112, notes that Whythorne's "life becomes, for the moment, a kind of running commentary on the poem it spawned." 
9 I adapt the phrase from Anne Righter, Shakespeare and the Idea of the Play (London, 1962; rpt. Harmondsworth, 1967). It is an important and insufficiently explored fact that the Elizabethan dramatists' fascination with the idea of the play develops almost simultaneously with the poets' fascination with the idea of the poem.

10 Apology, in Smith, I, 156.

11 The Autobiography of Thomas Whythorne, ed. James M. Osborn, modern spelling edition (London, 1962), p. 10; original spelling edition (Oxford, 1961), p. 18. Quotations from the Autobiography are from the modern spelling edition; parenthetical page references are given first to this edition and then to the original spelling edition.

12 Apology, in Smith, I, 160.

13 John Williams, ed., English Renaissance Poetry (New York, 1963), p. ix.

14 Autobiography (1961), p. lviii.

15 The structural similarity between Whythorne's Autobiography and Gascoigne's Adventures of Master F.J., published as part of the Flowres, is mentioned by Osborn, Autobiography (1961), pp. liv-lv, and developed by Gottfried, "Autobiography and Art," pp. 113-16. I hope elsewhere to demonstrate that the parallels between Whythorne and Gascoigne are more extensive and significant than either Osborn or Gottfried tend to suggest.

16 Cf. J.W. Saunders, The Profession of English Letters (London, 1964), pp. 49-67.

17 On the hostility to imaginative literature, see especially Russell Fraser, The War Against Poetry (Princeton, 1970), and Richard Helgerson, The Elizabethan Prodigals (Berkeley and Los Angeles, 1976).

18 Perhaps the urge to autobiographical coherence explains why the manuscript concludes with a group of almost seventy poems, devoid of commentary and merely introduced by some very brief remarks to the effect that they were the products of leisure and written after the previously narrated events. Whythorne introduces the affair of the twenty-pound widow with the words, "While I was preparing to print my music, there happened divers occasions to me to write more songs and sonnets... one of which was the following" (p. 150; p. 185). Obviously a degree of selection was involved in compiling the manuscript. It seems to me probable that the final group of poems comprises items that did not find a natural place in any of Whythorne's chosen narrative units, and that he decided to include them using a rather vague and catch-all statement of occasion.

19 C.S. Lewis, English Literature in the Sixteenth Century (Oxford, 1954), pp. 222-71, 464535 ; Yvor Winters, "The 16th Century Lyric in England: A Critical and Historical Reinterpretation," Poetry, 53 (1939), 258-72, 320-35; 54 (1939), 35-51; reprinted in Elizabethan Poetry: Modern Essays in Criticism. ed. Paul J. Alpers (New York, 1967), pp. 93-125.

20 The most important disciple is Douglas L. Peterson, The English Lyric from Wyatt to Donne: A History of the Plain and Eloquent Styles (Princeton, 1967); see also the introduction to John Williams, ed., English Renaissance Poetry.

21 Ben Jonson, Discoveries; Conversations with William Drummond of Hawthornden, ed. G.B. Harrison (London, 1923), p. 16.

22 Apology, in Smith, I, 156. 